\title{
Golden Jubilee for Golden Gate - A Concise History of Golden Gate Highlands National Park, 1963 to 2013

\author{
Dr Cobus Rademeyer
}

History Department, University of the Free State, Qwaqwa Campus, Private Bag X13,

Phuthaditjhaba 9866, South Africa

rademeyerjs@qwa.ufs.ac.za

Prof Willem van Zyl

Geography Department (Tourism), University of the Free State, Qwaqwa Campus,

Private Bag X13, Phuthaditjhaba 9866, South Africa

vanzylwf@qwa.ufs.ac.za

Doi:10.5901/mjss.2014.v5n27p1169

\section{Abstract}

The Golden Gate Highlands National Park has been the nucleus of tourism for the Free State Province and for the South African National Parks in this province for the last fifty years. Sadly very little has been written on the history and the development of this Park since its inception in 1963. APJ van Rensburg, amongst others, wrote a striking article on the history of the area before 1963, but the heritage and culture of Golden Gate Highlands National Park between 1963 and 2013 has been left virtually unexplored by historians. Various fragments of its history have been research, but the bigger picture was left largely untold. This article, as a concise account of the Park's past, attempted to, through qualitative research, form the basis of a research project exploring the different components which integrated to form the collective history of Golden Gate Highlands National Park since 1963. This initial research focussed primarily on limited primary and secondary sources and relied strongly on Park reports to fill the gaps caused through the loss of valuable historical documents in the veld fire that destroyed the Administration and Information Centre at Gladstone in 1987. Planned future research on historical subsections of the culture and heritage of the Park will be supplemented through interviews with influential individuals, the van Reenen family, local inhabitants and farmers, as well as documentation from various archives and private collections.

\section{Introduction}

On 13 September 2013, the Golden Gate Highlands National Park (GGHNP) celebrated its golden jubilee. As the major South African National Parks (SANParks) establishment in the Free State, the GGHNP reflected on a multitude of highlights over the past fifty years, and because of its natural beauty it has become a showcase in most of SANParks pictorial publications, calendars and coffee table books. The unique nature of GGHNP has also made it a favourite SANParks destination in the central part of South Africa. Although GGHNP is much younger than parks such as the Kruger National Park, which has been in existence for over a hundred years, the history of GGHNP is rich in cultural- and natural heritage.

The use of the word "concise" in the title of this manuscript highlights the fact that certain historical events and issues mentioned in this document are mere highlighted and will be addressed in more depth in future. In this regard this document can be regarded as the first in a series of historical perspectives on GGHNP. Topics such as the amalgamation of GGHNP and the Qwaqwa National Park, the San rock art, the Basotho Cultural Village and other related topics, which are only mentioned in passing in this document, will therefore be addressed in more depth in future.

\section{Early History of the Golden Gate Area}

The early history of the Golden Gate area is highlighted by dinosaur remains, rather than by remains of humans. In 1978, Professor James Kitching discovered the first and oldest dinosaur eggs in GGHNP (Harvey 2003). This unearthing of the nest of a Massospondylus, mid-sized dinosaur from the early Jurassic period was regarded as a ground breaking discovery (Dean, 2012). Scientists believe this site in GGHNP to be the oldest "dinosaur nursery" with the discovery of 
dinosaur eggs, some still with embryos, and tiny dinosaur footprints (Smillie, 2012). At least ten nests were discovered and each nest had up to 34 eggs in it. The nesting ground is, according to the scientists, more than 100 million years older than any other previously known sites.

The San people were the first human inhabitants of the GGHNP area. Beautiful examples of San paintings on certain rock faces in the Park confirm the historical fact that the San people preceded the black people (Labuschagne, 1969), while the movement of white people to this area is documented to take place later. Bert Wodehouse in The Rock Art of the Golden Gate and Clarens districts has done extensive research on rock art in this area; therefore, it will not receive much attention in this script.

Evidence of Basotho cultural and farmer settlements also reflects the Park's rich cultural content and heritage (SANParks, 2011). Therefore, it is necessary to give a brief background of the history of the Golden Gate area before 1963. Different resources indicate that this area must have been a hunter's paradise at the start of the nineteenth century. According to Van Rensburg, the Voortrekker diary of Rev Erasmus Smit, and later the Roos family, who in the nineteenth century lived on the farm Elandsfontein, between Bethlehem and Golden Gate, recorded more than 300 lions killed in this area during a single year (van Rensburg, 1968). The presence of lions in this area clearly indicates that there had to be large volumes of game in the Golden Gate area during the nineteenth century.

The Golden Gate area also played host to many conflicts between Black and White during the nineteenth century. The battle for black supremacy between Sekonyela and Moshoeshoe took place in this area before Moshoeshoe decided to move south to Thaba Bosiu.

Conflicts between Black and White led to the proclamation of the Free State as British territory by Sir Harry Smith in 1848. This meant that the Golden Gate area, for the first time in its history, became part of the mighty British Empire. Due to clashes between Black and White in the area, the British proclaimed the Warden line in 1849, which divided the territory between the British territory and Basutoland. As a result, the Golden Gate area once again became part of Sekonyela's territory. This led to renewed conflict between Sekonyela and Moshoeshoe, as well as renewed conflicts between Black and White.

After the First Basotho War (1858), the Free State Republic signed a peace treaty with the Basotho, which resulted in Moshoeshoe regaining areas previously owned by Sekonyela, including Golden Gate. This area changed ownership again when the Free State- and Transvaal Republic defeated the Basotho in the Second Basotho War (1865). The creation of the so called "concurred area" between the Republic of the Free State and Basutoland, led to Golden Gate becoming part of the Free State Republic again. The peace treaty of Aliwal North in 1869 ended the turbulent period for Golden Gate and within ten years this area became prime agricultural land again.

Between 1860 and 1862, the Golden Gate area experienced one of the severest droughts in its history. Thousands of cattle and sheep died because of the drought. Game was hunted by both Black and White to ensure more grazing for their cattle and sheep and to ensure meat for their families in time of the drought. This culling of game and associated game hide trade in this area during the early 1860 s, is today still regarded the most brutal in South African wild life history (Van Rensburg 1968).

After signing the peace treaty in 1869, the concurred area between the Free State and Basotholand was divided into three rows of farms, each 1500 morgen in size. Three farms of importance in this concurred area are Noord-Braband (no. 61), Vuurland (no. 62) and Witziesoorsprong (no. 63). These three farms would eventually amalgamate in 1963 and be proclaimed as the Golden Gate Highlands National Park. In 1880 fifty-eight morgen of the farm Noord-Braband was sold to JNR van Reenen, the owner of the neighbouring farm Vuurland. A year later, on 8 July 1881 Van Reenen registered this piece of land as Golden Gate (Van Rensburg 1968).

The Golden Gate area did not escape the brunt of the Anglo-Boer War (1899 - 1902) unscathed. The scorch earth policy implemented by the British ensured that farm houses were burned to the ground, sheep and cattle killed or driven away, crops burnt, and most woman and children were removed from the farms and taken to concentration camps. In the post-Anglo Boer war period the Golden Gate area saw a change from mainly stock farming before the war to a stronger concentration on crop- and dairy farming after 1904. The establishment of the town of Clarens in 1912 ensured that Golden Gate would in future be in touch with the outside world through a post office, police station and a telephone line. The new town also led to the establishment of a school and ensured the increased growth in population of the area.

Clarens continued to grow and in 1920 it received municipal status and the first church came to being. Since then gradual, peaceful progress in the development of the town and the Golden Gate area transpired.

At the same time the initial farms Noord-Braband, Vuurland and Witziesoorsprong expanded, changed hands and in some instances changed names, thus in 1962 the farms Gladstone, Wilgerhof, Melsetter, Golden Gate, Glen Reenen, Wodehouse and Zuluhoek bordered each other in a collective unit, once known as sections of the three farms named above. 
At that stage Golden Gate, as this area was then known, has become renowned for its breath taking camping sites and picnic areas, and people from all parts of South Africa who visited Golden Gate started voicing their opinion that Golden Gate should become a National Park.

\section{Proclamation of the Golden Gate Highlands National Park}

The Free State Administrator JWJC (Sand) du Plessis and his Executive Committee formally started working on the idea of converting Golden Gate into a national park. The Free State administration met with the Board of Trustees of National Parks in 1962 to discuss the establishment of a national park in the Free State province. After a visit to Golden Gate the Director of National Parks, Rocco Knobel, remarked:

The mountainous nature and -view of the area is unique in our country and that definitely justifies national park status...in this mountainous area you will find the highlands with a climate, fauna, and features that typifies the Highveld of South Africa. The National Parks Board foresees that it will be possible to develop an interesting and potentially renowned park here that would contribute positively to the framework of existing national parks (Van Rensburg 1968).

As a result, on 18 June 1962, the Provincial Administration of the Orange Free State approved the purchase of the farms Gladstone, Wilgerhof, Melsetter, Golden Gate, Glen Reenen, and Wodehouse, at a total cost of R 187662,00 (Van Rensburg 1968) for a nature reserve. The province would then offer this land to the National Parks Board for the development of a national park. The area purchased was concentrated around the popular picnic site at Golden Gate and would form the core of a project, which will support the creation of the first national park in the Free State (SANParks 2013). The Parks Board accepted the offer and on 7 September 1962, the Board of Curators decided that the new park be called the Golden Gate Highlands National Park. The name Golden Gate for the area came about through a suggestion by one of the family members, who once owned the farm. The term Golden Gate is a resultant of the exposed yellowish sandstone of the iconic Brandwag structure glowing in the evening light (Ewart-Smith 2010). The Golden Gate area is still regarded by photographers as very photogenic, no matter in which season you visit. This contributes to the popularity of the Park.

With the transfer of this land to the control of the then South Africa National Parks Board, an initial core area of 1,792 ha formally became the Golden Gate Highlands National Park on 13 September 1963 (SANParks 2013). The first State President of the Republic of South Africa, CR Swart, proclaimed the GGHNP as a National Park in accordance with notice 259/1963 and article 2 of the Law on National Parks of 1962, within the district of Bethlehem in the Eastern Free State. A visit of the State President and other dignitaries on 16 October 1963 symbolised the Park's official opening.

The first overnight visitors to the Park entered GGHNP on 29 September 1963, and since then the overnight facilities within the Park started increasing. During that same year the rest camp at Glen Reenen was revamped by converting the old farm buildings into tourist accommodation (SANParks 2013), with thirteen rondavels and a camping area soon added to the rest camp.

The Brandwag chalets, with 35 semi-luxury tourist accommodation, were finished in 1968. The Brandwag complex, the new main building of GGHNP, was officially opened on 24 March 1972. The complex consisted of 34 luxury rooms, two dining halls, a reading and recreation room; and provision made for horse-riding, trout fishing, swimming, tennis, bowls and a 9-hole golf course (SANParks 1972).

\section{Growth and Development of the Golden Gate Highlands National Park}

When Zuluhoek (5 462 morgen) was bought by the National Parks Boards and mr Pierre Maree donated Kalieskraal (500 morgen) to the Parks Board in 1966, only Noord-Brabant was left outstanding of the unit that initially formed the two farms in the conquered territory (Van Rensburg 1968). The addition of Noord-Brabant to GGHNP in 1980 completed this picture, and was regarded as one of the highlights of the 1980/81 season for GGHNP (SANParks 1981a).

In 1977, the Park received appropriately demarcated maps, which clearly indicated the borders of GGHNP (SANParks 1978a). Once the borders were finalised the outer fencing of the Park were elevated and secured with chicken mesh, to animal proof it. Officials decided that no entrance fee be charged to GGHNP, in view of the public road (the R712) that would be fenced off on both sides of the park (Reitz 1972). In 1981 GGHNP's income exceeded one million rand for the first time (SANParks 1981b), and in April 1984 GGHNP reached the 90\% bed occupation rate for a month, for the first time (SANParks 1985a). These achievements were a clear indication that the Park had grown to a prominent component in the SANParks team, with tourist numbers increasing all the time. 
In 1988, after six years of negotiations, 12 farms adjacent to the Park were added to GGHNP, increasing the area under conservation from 5389 ha to 11630 ha (SANParks 1989). The Brandwag Hotel, regarded by many as the main man made attraction in GGHNP, closed for renovations to the tune of thirty million rand between February 2009 and 2010 (Van der Merwe 2010). The name of the hotel also changed from Brandwag Hotel to the Golden Gate Hotel. Over the years the Glen Reenen rest camp was upgraded and the Gladstone administration complex received a facelift. Earlier in the new millennium the Highlands Mountain Retreat, with eight luxury log cabins, was built, self-catering chalets were developed at the Basotho Cultural Village and the historical Noord-Brabant farmhouse was restored to its former glory.

\subsection{Wildlife/ Fauna}

The Parks Board had to re-introduce nearly all the different species of animals which originated from this area (Labuschagne 1969). Even before the State President could proclaim GGHNP a National Park, the Parks Board started stocking the area with game. Five red hartebeest arrived in the Park on 25 May 1964, followed by blesbuck from the Willem Pretorius Nature Reserve, and more red hartebeest and black wildebeest from the Kalahari (Van Rensburg 1968). Soon there were herds of eland, black wildebeest, blesbuck, springbuck, red hartebees and zebra roaming the grasslands of GGHNP. While grey and red rhebuck started moving around the slopes and streams, warthogs and ostriches were re- introduced into the area.

The animal census of 1973 showed that most of the antelope adapted very well to the area. An interesting fact is that there were 13 buffaloes in the Park that year, and it was noted in the respective annual report that the 1973/74 season was the first for buffalo and oribi births in the new National Park. Four buffalo calves were born during that season, and three oribi lambs (SANPark 1974). The most prominent antelope in the Park in 1973/74 were blesbuck (532), black wildebeest (343), springbuck (213) and mountain reedbuck and grey rhebuck.

The buffalo numbers drastically declined in 1974 when eight of the 13 animals died, presumable because of poisoning by the yellow tulip (Moraea Spathulata) found mainly in the kloofs at Zuluhoek (SANParks 1975). Sadly, the number of buffaloes dropped to two in the 1979/80 census (SANParks 1980a), and in the 1985 animal census no mention is made of the buffalo population in the Park.

Another interesting fact worth mentioning, is that in both 1973 and 1974 the warthog population in the Park counted only three. No mention is made of the warthog numbers in later annual reports, therefore one can assume that the warthogs also either died or relocated.

The air census done by helicopter in March 2010, the last official game census in the Park (SANParks 2012), indicated that there are 2380 blesbok, 1043 black wildebeest, 707 eland, 1039 red hartebeest, 450 springbuck and 1008 Burchell's zebra in GGHNP. Apart from the above-mentioned animals, there were also smaller amounts of grey rhebok (140), mountain reedbuck (15) an undisclosed number of oribi's and ostriches (6) in GGHNP.

The 1974 bird observations identified 59 prominent bird species (listed according to the Roberts Bird Catalogue) in GGHNP (SANParks 1980a). This number increased to 100 identified bird species in 1979 (SANParks 1980b); 123 different species in 1983 (SANParks 1983); and by 2010 the number increased to 176 species (SANParks 2012). In 1993, a vulture restaurant, with a panoramic view of the Maloti/Drakensberg range, came to being in the Park. In 2012 the SANParks Honorary Game Rangers, built a vulture hide that looks out on the vulture restaurant. This vulture hide, built thanks to a sponsorship by SASOL, operates as part of the international vulture conservation programme in Southern Africa (SANParks 2005).

According to the GGHNP Annual Reports game poaching created problems in the Park since 1963. At times this increased, and then declined again. In general the problem was addressed with great success by the park management over the years, in partnership with the local police, surrounding farmers' unions and tip-offs from visitors to the Park.

\subsection{Horses and donkeys in the Park}

The impassability of the terrain within GGHNP made the Park management realise, at a very early stage, that the only way to access all areas of the Park was on horseback. Therefore the first horses were bought by the Park in 1963, making them interwoven with the history of GGHNP (Van Zyl 1976). Donkeys were bought to transport material up the mountain to where the first fences had to be erected. Tourists to the Park saw the horse and asked whether they could ride the horses. This started a long tradition of horse riding that would become very popular and one of the great tourism attractions in GGHNP.

By 1981, there were 40 horses in GGHNP, and the horse- and pony rides became increasingly popular with tourists (SANParks 1981b). In 1982 a total of 1300 rides were undertaken on the horses and ponies (SANParks 1983) in 
the Park and while the horse- and pony population in the Park grew, so did their popularity among the tourists. This resulted in the Park making 106\% more than the estimated profit for the year 1984 (SANParks 1985a). Although the horses were very popular with the tourists, they also functioned on a regular basis (about one-third of the time) in the Park for patrols, fence checks and other duties. With the last officially documented game census in GGHNP, done in 2010 , a total count was done of 80 horses and 35 donkeys in the Park.

\subsection{Flora}

For the purpose of this article, not much emphasis will be placed on the flora of GGHNP, since extensive research and publications have already been done on this matter, especially by Rodney Moffett, retired professor and currently a research fellow in Plant Sciences at the Qwaqwa Campus of the University of the Free State. It should however be mentioned that, throughout the history of the Park, substantial work was done to excavate and destroy large quantities of alien trees in GGHNP. This included black wattle-, willow-, poplar-, pine- and eucalyptus trees (SANParks 1987b). These excavation activities are well planned and documented in the respective annual reports during the research period.

\subsection{Veld fires and rotational burning in the maintenance of grazing areas in the Park}

During the 1977/78 season it was realised that the game camp in GGHNP was heavily overgrazed and in severe contrast to the Wodehouse - Wilgehof area where the grazing was in excellent condition. To counter this problem the Park merged into one unit by removing the fences along the national road, and moving the surplus animals from the overgrazed area (SANParks 1977a).This led to the realisation that the grazing areas needed to be better managed to ensure optimal grazing conditions for the animals in future.

Winter in the Eastern Free State has always been associated with veld fires and strong winds. This has been a problem for the Park management at GGHNP; thus, they implemented a consolidated plan to ensure it was prepared for veld fires and that the fighting of veld fires was well managed.

Research has shown that planned rotational burning led to a better hibernation programme of areas characterised with extreme winter climate, as in the case of GGHNP. Since 1978 the prominent grazing areas were burned on rotation basis every September. The primary aim behind this was to achieve an equitable grazing usage pattern for the prominent antelope species in different areas (Van der Walt \& Van Zyl 1982). This was necessary because overgrazing in selected areas started showing serious consequences. In 1984, the Park management started using backpack water sprays in remote areas to ensure that rotational burning did not get out of hand in remote areas, far from roads or tracks (SANParks 1984). Packhorses and donkeys were utilised to cart water to these areas.

On 26 February 1987, the Administration and Information Centre at Gladstone was set alight and destroyed by lightning. Equipment of more than R 50000 was destroyed in the fire, the herbarium, as well as all reports and historical data on nature conservation (SANParks 1987b). The magnitude of loss of information cannot really be determined, but as was realised in the research process of compiling this article, a considerable amount of valuable information was lost in the fire.

During the winter of 1988, a case of arson led to a veld fire on the eastern side of the Park, destroying the grazing on all but part of one of the twelve farms that became part of GGHNP (SANParks 1989). The next year large areas bordering the park towards Qwaqwa and Lesotho were torched by the local communities (SANParks 1990). This indicated that arson and veld fires could become a big problem in future, and cross-border discussions would have to take place to address this potential problem.

One of the worst veld fires in the Park's history destroyed more than 6000 ha, which was then half of GGHNP, in June 1992 (Smith 1992). Repeated veld fires destroyed two-thirds of GGHNP and large areas of the surrounding farms at the end of August 2000. Many animals died in the Park and in the adjacent Qwaqwa National Park (de Klerk \& Motabogi 2000). During the 2007/8, season game rangers and Working on Fire teams fought 76 uncontrolled fires around the park (SANParks 2008). In August 2009, 7500 ha of GGHNP was destroyed in a fire. The next month nine of the twenty-four chalets at the Basotho Cultural Village incurred damages in a veld fire, causing damages estimated at more than five million rand (Bürger 2009).

Veld fires are a constant threat to all National Parks in South Africa, but given the climate, nature and terrain of GGHNP, veld fires will always pose an added threat to this park. Therefore, there was a need for the planning for rotational burning in the maintenance of grazing areas. 


\subsection{Environmental Educational programmes}

Since 1979, GGHNP offered environmental education courses to school children, and by 1991, more than 30000 children were educated in various aspects linked to nature conservation. The courses included a sleep over in one of the caves in the Park and created a new generation of nature conservationists and nature-conscious children/scholars. The course was launched with 12 schools in 1979, but by the mid-eighties, it had already grown to 68 schools (SANParks 1984). From the feedback, it was clear that the courses were generally well received. The courses that were presented were constantly reviewed and changed according to the needs and desires of the planned programmes and initiatives. Wilgenhof Youth hostel accommodated large groups at a time, and various youth symposiums were held on a regular basis in GGHNP.

In 1986, Mmabatho High School became the first Black school to participate in the youth symposium (SANParks 1987a). Since then the youth symposiums started to develop a more integrated approach and accommodated a wider spectrum of schools, which culminated in improved results.

By 2004/5 an annual number of 2991 participants took part in 60 environmental education programmes at the Wilgenhof Environmental Education Centre (SANParks 2005). Environmental education, including the "Kids in the Park" programme, showed a healthy growth and in 2007 a total number of 4040 participants took part in 87 environmental education activities at the Wilgenhof Environmental Education Centre, totaling 8915 notional education days.

The Environmental Education programmes were partnered by the so-called "Kids in the Park" programme, which combined education with outdoor activities such as hiking, abseiling, and horse riding. The "Kids in the Park" initiative was applied in GGHNP with great success and while driving through the park during certain times of the year, one can still hear and see the enthusiasm of the children as they enjoy the beauty and tranquility of the area.

\subsection{Upgrading of the road}

As early as 1973, the gravel road through GGHNP created problems. Due to heavy rain in January and February, the road through the game camp was unusable because of flooding (SANParks 1974). In the 1977/78 season, grading of the road took place twice, but due to a lack of top soil, it was not very successful (SANParks 1977b). This led to the road been re-gravelled, but due to the unavailability of proper equipment, the progress was very slow. This problem regarding the gravel road continued and in 1978 the Park management indicated that the only permanent solution would be to tar the road (SANParks 1978b). This decision came about after continuous heavy rains made some of the roads in the Park virtually impassable.

The main reason why fewer tourists from Natal visited GGHNP in 1985 was due to the poor condition of the gravel road from the eastern entrance to Harrismith and Qwaqwa (SANParks 1985b). By 1988, the tar road in the Gladstone area was completed, and two roads in the game watching areas received tar surfaces (SANParks 1988). Two years later, all tourist roads in the park had tarred surfaces.

During the period 1992 to 1995 a section (P31-3) of the R712 national road, which leads through GGHNP and the then Qwaqwa National Park was upgraded from an "unsurfaced narrow road" to a tarred road (Schoof 1998). This was originally a dirt road meandering along the middle and lower slopes of the Red Mountains, linking the Free State with KwaZulu-Natal. Owing to the poor condition of the existing road, and in order to provide a quicker link between Bloemfontein and Phuthaditjhaba, a decision was taken to upgrade the road. Throughout the 1980s Annual- and Progress Reports from GGHNP frequently referred to the "tourist roads which are in an unsatisfactory state of repair" (Schoof 1998). During the initial phase of the project, both the National Parks Board and the Free State Provincial Administration realised the multiple challenges they faced in upgrading the road through this mountainous area, but the flipside of the coin was the realisation that the improved infrastructure would lead to speeding and higher traffic volumes through the Park.

\section{Incorporation of Qwaqwa National Park into GGHNP}

On 18 March 2004 the Minister of Environmental Affairs and Tourism, mr Valli Moosa and the MEC of the Free State Province, mr Sakhiwo Belot, signed a memorandum of understanding for the incorporation of the Qwaqwa National Park into GGHNP. In his speech afterwards mr Moosa referred to this occasion by saying:

By gathering here today and making this pledge together with the people of the Free State, we are beginning a process of reconnaissance into ways of making natural resources work for all of us. (Moosa 18 March 2004) 
The aim of extending the Park to the borders of Lesotho and Qwaqwa was to make it a meaningful environmental management unit. Initial talks regarding the amalgamation started nineteen years earlier, but only materialised in 2008 a period regarded by many as a watershed year in the history of GGHNP.

During this time, the Minister of Environmental Affairs and Tourism reopened discussions for the incorporation of the Qwaqwa National Park into GGHNP. This process culminated in the Minister publishing the declaration of the 95 properties that made up the Qwaqwa National Park as part of GGHNP in the Government Gazette on 21 November 2008 (SANParks 2009). The declaration of the former Qwaqwa National Park in November 2008 as part of the GGHNP added 21128 ha of grassland to the existing 11630 ha Park, thus greatly enhancing both the biodiversity value and tourism viability of this Park. After consolidation, the enlarged GGHNP covered 32758 ha, increasing the Park to three times its original size of 1963 (SANParks 2009). Major challenges were associated with the incorporation, including the reestablishment of fences, finalising budget issues and unlocking the immense tourism potential and opportunities of the new enlarged park.

The Qwaqwa National Park originated in February 1991. The Park consisted of former farmland on which the farmers and agricultural labourers remained, after the Park was proclaimed. Conflict in the Park stemmed from the Park's longstanding inhabitants, who grazed their cattle on rented land, which was now part of the Park. They were unhappy for not being consulted about the establishment of the Park (Slater 2002). This land claim/ownership conflict continued long after the Qwaqwa National Park became part of GGHNP and by 2013 some of the land issues within GGHNP were still not been resolved. As a result, the game census in 2010 mentioned that there were 530 sheep, 70 goats and 1080 cattle in the Park, which belong to farmers that still resided in the Park at the time. These agricultural animals are still in the Park today.

The Qwaqwa National Park proclaimed in January 1992 according to Section 18 (1) of the Qwaqwa Nature Conservation Act (No. 5) of 1976, bordered the GGHNP from the south-eastern part of Golden Gate, in the shape of a horseshoe, to the north of GGHNP (SANParks 1991). It was therefore inevitable that the two parks had to think of amalgamation at some stage. The National Parks Board and Highlands Development Corporation came to a principle agreement in 1993 to dismantle the communal boundary fences between the two parks (SANParks 1994).

\section{Basotho Cultural Village}

A large part of the unique wealth of GGHNP lies in the rich cultural history of the area, with the Basotho Cultural Village forming an integral part thereof. This cultural centre is a living museum, tracing the lifestyle and social trends of the Basotho from the previous centuries - a simulated village through which the story of the Basotho people is told. It focusses on the Basotho culture, tradition, and even architecture, depicted in a unique way for tourists to enjoy.

The Cultural Village Rest Camp, opened in the eastern part of GGHNP in January 2009, contributes to the accommodation facilities of the Park with 24 units built in the traditional Basotho style, to fit in with the rest of the Cultural Village (Van Staden 2011). The chalets, which can accommodate 72 people, although developed and shaped in the form of a traditional Basotho kraal, have the luxuries of modern facilities like running water and beds for tourists.

\section{GGHNP Visitor Numbers}

Research done by the University of Pretoria showed that more than sixty percent of visitors to GGHNP between 1961 and 2011 were returning visitors (60,7\%), while only $39,3 \%$ of the visitors were first time visitors (Botha 2012). These statistics support the fact that GGHNP is very popular with tourists and has a very high return rate. Research in the late 1970's showed that half of the domestic visitors to the Park came from the old Transvaal province ( $50 \%$ by 1978), while only $18 \%$ of the visitors came from the Free State. International visitors to GGHNP (3\% of the overall visitor numbers) mainly came from England, Western Germany, the United States of America and Australia (SANParks 1978b). By 1981 the international visitors list also included strong contingents from the Netherlands, Switzerland and France (SANParks 1981b). 
Table 1: Visitor numbers to GGHNP, 2003 to 2013 (Obtained from respective SANParks Annual Reports).

\begin{tabular}{|c|c|}
\hline Year & Number of visitors to Golden Gate \\
\hline Ending March 2004 & 19035 guests \\
\hline Ending March 2005 & 21870 guests \\
\hline Ending March 2006 & 25101 guests \\
\hline Ending March 2007 & 32688 guests \\
\hline Ending March 2008 & 39172 guests \\
\hline Ending March 2009 & 37399 guests $^{\star}$ \\
\hline Ending March 2010 & 34090 guests $^{\star}$ \\
\hline Ending March 2011 & 38758 guests \\
\hline Ending March 2012 & 41056 guests \\
\hline Ending March 2013 & 42390 guests \\
\hline
\end{tabular}

* Visitor numbers during this period dropped because Golden Gate Hotel and certain chalets closed for business due to refurbishment from 19 January 2009 to early March 2010.

Overnight visitors to the Park have a range of tourism products. If the accommodation facilities in GGHNP are fully booked, with the maximum possible number of people per unit, 636 visitors can be accommodated (Visser \& Kotze 2003).

\section{Conclusion}

Golden Gate Highlands National Park can indeed look back on fifty years of prosperity. As the Chief Executive Officer of SANParks, dr David Mabunda mentioned in his address at the fifty years' celebrations, GGHNP has always been a unique national park in South Africa. The reason for this, he said, was the fact that the Park and its activities are concentrated around a hotel (Mabunda 13 September 2013). Add to this the comment made by the then Park Manager, Corrie Pieterse, in 1987: "The surroundings - nature, rock formations and climate - still remain Golden Gate's biggest drawing card" (SANParks 1987b), and you will soon realise that GGHNP is not like all the other National Parks in South Africa. Although it does not host the big five, GGHNP offers far more than only wildlife.

Apart from the surroundings, rock formations, sandstone, climate and a photographer's favourite playing ground, it also hosts a variety of natural and cultural heritage sites still unexplored. The golden shade of the setting sun against the eastern Free State sandstone not only reflects the beauty of this park and its animals, but also the heritage of the place many people have called home.

\section{References}

Botha, M., 2012, "The role of Biodiversity in National Parks on visitor experience: A Case study of Oulanka Park in Finland and Golden Gate Highlands National Park in South Africa". University of Pretoria: Unpublished M.Com dissertation.

Bürger, V., "Basotho-dorpie erg deur brand beskadig". Volksblad, 9 September, 2009, p. 2.

De Klerk, N. \& Motabogi, C., "Vlammehel verwoes groot dele van die Oos-Vrystaat". Volksblad, 1 September, 2000, p. 1.

Dean, S., "Dinosaur nest discovered". The Citizen, 26 January, 2012, p. 3.

Ewart-Smith, C., "Golden Gate". Getaway, October, 2010, pp. 38-46.

Harvey, K., "Gates of time". The Citizen, 24 May, 2003, p. 19.

Labuschagne, R., 1969, Our National Parks. A Guide to National Parks in South Africa. Revised ed. Pretoria: National Parks Board of the Republic of South Africa.

Mabunda, D., 13 September 2013. Official speech, Golden Gate Golden Jubilee celebration. Golden Gate Hotel: s.n.

Moosa, M., 18 March 2004, Basothu Cultural Village: http:://www.info.gov.za/speeches/2004/04031813461001.htm.

Reitz, J. d. V., 1972, A Guide to National Parks, Game and Nature Reserves of Southern Africa. Cape Town: South African Nature Foundation.

SANParks, 1974, Golden Gate Highlands National Park Annual Report 1973/74, s.l.: SANParks.

SANParks, 1972, Golden Gate Highlands National Park. Custos, February, p. 11.

SANParks, 1975, Golden Gate Highlands National Park Annual Report 1974/75, s.l.: SANParks.

SANParks, 1977a, Golden Gate Highlands National Park Midyear Report 1 April to 30 September 1977, s.l.: SANParks.

SANParks, 1977b, Golden Gate Highlands National Park Report April to September 1977 (Technical Report), s.l.: SANParks.

SANParks, 1978a, Golden Gate Highlands National Park Midyear Report 1 October 1977 to 31 March 1978 (Management Report), s.l.: SANParks.

SANParks, 1978b, Golden Gate Highlands National Park Midyear Report October 1977 to March 1978 (Technical Report), s.l.: 
SANParks.

SANParks, 1980a, Golden Gate Highlands National Park Annual Report 1979/80, s.l.: SANParks.

SANParks, 1980b, Golden Gate Highlands National Park Midyear Report April 1979 to March 1980 (Research Report), s.l.: SANParks.

SANParks, 1981a, Golden Gate Highlands National Park Annual Report, 1 April 1980 to 30 March 1981, s.l.: SANParks.

SANParks, 1981b, Golden Gate Highlands National Park Annual Report, 1981, s.l.: SANParks.

SANParks, 1983, Golden Gate Highlands National Park Annual Report 1982/83, s.l.: SANParks.

SANParks, 1984, Department of Inland National Parks Progress Report April to September 1984, s.l.: SANParks.

SANParks, 1985a, Golden Gate Highlands National Park Annual Report, 1 April 1984 to 31 March 1985, s.I.: SANParks.

SANParks, 1985b, Golden Gate Highlands National Park Semi-Annual Report 1 April to 30 September 1985, s.l.: SANParks.

SANParks, 1987a, South African National Parks Research and Information Annual Report 1 April 1986 to 31 March 1987, Pretoria: SANParks.

SANParks, 1987b, South African National Parks Inland Parks Annual Report 1986/87, s.I.: SANParks.

SANParks, 1988, South African National Parks Inland Parks Annual Report 1987 - 1988, s.l.: SANParks.

SANParks, 1989, South African National Parks Inland Parks Annual Report, 1988 - 1989, s.l.: SANParks.

SANParks, 1990, South African National Parks Inland Parks Annual Report 1989/90, s.I.: SANParks.

SANParks, 1991, South African Natioanl Parks Board Annual Report 1990/91, Pretoria: SANParks.

SANParks, 1994, Golden Gate Highlands National Park Annual Report April 1993 to March 1994, s.l.: SANParks.

SANParks, 2005, South African National Parks Annual Report, 2004/5, Pretoria: SANParks.

SANParks, 2008, South African National Parks Annual Report 2007/8, Pretoria: SANParks.

SANParks, 2009, South African National Parks Annual Report 2008/9, s.I.: SANParks.

SANParks, 2012, South African National Parks Annual Report 2012, Pretoria: SANParks.

SANParks, 2011, Golden Gate Highlands National Park Management Plan, 2011, Pretoria: SANParks.

SANParks, 2013, Golden Gate Highlands National Park Management Plan 2013 - 2023, s.l.: SANParks.

Schoof, N., 1998, "An Environmental Audit of the Road Section (P31-3) in the Golden Gate Highlands National Park". Rand Afrikaans University: Unpublished M. Sc. Thesis.

Slater, R., 2002, Between a rock and a hard place: contested livelihoods in Qwaqwa National Park in South Africa. The Geographical Journal, 168(2), pp. 116-129.

Smillie, S., "The pitter-patter of dinosaur feet.... ".The Star, 26 January,2012, p. 3.

Smith, C., "Brand verwoes helfte van Golden Gate". Volksblad, 27 June, 1992, p. 2.

van der Merwe, J., "Golden Gate beter as ooit". Volksblad, 10 August, 2010, p. 4.

van der Walt, P. \& Van Zyl, L., 1982, "Die invloed van veldbrand op bewegingspatrone van wildsbokke in die Golden Gate-Hoogland Nasionale Park". Koedoe, Issue 25, pp. 1-11.

Van Rensburg, A., 1968, "Golden Gate, die geskiedenis van twee plase wat 'n Nasionale Park geword het". Koedoe, Issue 11, pp. 83137.

Van Staden, C., "Park wys 'n ryk natuur-, kultuurlewe". Volksblad, 23 February, 2011, p. 9.

Van Zyl, A., 1976, "Horses and the Golden Gate Highlands National Park". Custos, October, pp. 37-41.

Visser, G. \& Kotze, N., 2003, "A road runs through it. Tourism infrastructure development in the Golden Gate Highlands National Park". Africa Insight, 33(1), pp. 55-62. 